\title{
WHEN PROPHECY FAILS? THE THEOLOGY OF THE OSLO PROGESS-RABBINICAL RESPONSES TO A CRISIS OF FAITH
}

The Oslo process began with secret negotiations between Israel and the Palestinian Liberation Organization (PLO), and led to the signing of a declaration of principles by the two sides in Washington, DC in 1993. Israel agreed to withdraw from territories in the Gaza Strip, Judea and Samaria, and to establish a Palestinian autonomous authority in the area for an interim period, with a view to reaching a permanent settlement between the sides.

This process, and particularly the territorial compromise it entailed, created a profound crisis within those religious Zionist circles that have identified Israeli reality as part of a process of redemption. The political concessions threatened to disrupt their messianic expectations and required a response adapted to the new reality.

Accordingly, the Oslo process provides a test case for the way in which the religious Zionist public as a whole faced this crisis of faith, and, more specifically, the manner in which the Halachic guides of this public-those responsible for shaping its religious behavior-responded to this crisis.

This article will examine the attitude of the rabbinical leadership of the settlers toward the Oslo Accords, and will present the distinct responses of two rabbis-Yehuda Amital and Zvi Tau. The case studies will demonstrate how messianic believers face their prophetic failure and the modalities they apply in order to cope with it. Thus, the article will shade a new light on what happens when prophecy fails; However conditions are somewhat different. The Oslo process creates fear of a failure of faith due to the shattering of the vision of the Whole Land of Israel, but it has not yet been proved beyond doubt that redemption has failed. The study will show that messianic failure may in certain circumstances, lead to religious strengthening, but the opposite situation-of a retreat from messianic faith-is also possible. Accordingly, I shall seek to identify the circumstances that lead to these distinct responses. 


\section{GUSH EMUNIM}

The Six Day War (June 1967) created a new reality in the Middle East. In the course of the war, Israel occupied the West Bank, the Gaza Strip, the Golan Heights and the Sinai Peninsula. These areas were not annexed to Israel, and have continued to have the status of occupied territories administered by Israel pending their return in the framework of a peace agreement. Accordingly, immediately after the war, Israel did not, on the whole, initiate Jewish settlement in the occupied areas, with the exception of East Jerusalem, which was formally annexed to the State of Israel. From the outset, however, this principle was not strictly applied, and soon after the war a number of Jewish settlements were established in the occupied territory.

In 1973, the Arab armies launched a surprise attack on Israel. Although Israel eventually won the war, the Israeli public was shocked and angered by the large number of fatalities and by the military weakness shown in the battles. Following the war, U.S. Secretary of State Henry Kissinger began a shuttle diplomacy mission intended to lead to a ceasefire between the sides, and including Israeli territorial concessions.

Against the background of this shuttle diplomacy, the Gush Emunim ("Block of the Faithful") movement was founded with the objective of creating settlements in the occupied territories in order to prevent concessions. Gush Emunim was established in February 1974 by a group of young religious Zionist activists, and advocated the application of Israeli sovereignty to Judea, Samaria, and the Gaza Strip.

At the time of its establishment, Gush Emunim did not expound a messianic message; it developed as a coalition of forces from the religious kibbutz movement and from bourgeois urban circles, together with secular supporters of the Whole Land of Israel movement. ${ }^{1}$

The first settlement action undertaken by activists from the organization, came when they entered a site in Sebastia without official permission. The authorities evicted the settlement several times, but the settlers then reached an agreement with Minister of Defense Shimon Peres that they would be housed in a neighboring IDF base-a decision that effectively led to the establishment of the settlement, despite some opposition within the Israeli government led by Yitzhak Rabin. After the Likud came to power in 1977, the pace of construction in the settlements increased, and they enjoyed enthusiastic support, including financial benefits, the construction of infrastructures, and legal protection. Since then, the number of Israeli citizens living in the settlements has risen steadily. ${ }^{2}$ At the beginning of 2004, 
the population of the settlements was estimated at 250,000, and some forty percent of the territory of Judea and Samaria was included in the municipal areas of jurisdiction of the settlements.

The newly created Gush Emunim was joined by a group of graduates of Mercaz Harav Yeshiva, headed by the spiritual leadership of Rabbi Zvi Yehuda Hacohen Kook (1891-1982). The members of this group soon assumed leadership roles in the movement. The graduates of Mercaz Harav hold a religious perspective that motivates them to political action. They believe that the return of the Jews to the Land of Israel under the auspices of the secular Zionist movement reflects the first stage in God's will to redeem His people. Accordingly, the spectacular Israeli victory in the Six Day War of 1967 is perceived as a manifestation of the Divine plan, and as a preliminary stage in the process of redemption.

Merkaz Harav followers see themselves implementing the philosophy of Rabbi Avraham Yitzhak Hacohen Kook (1865-1935). ${ }^{3}$ According to Kook, while ostensibly adopting the general Zionist definition of the movement's purpose, this definition was imbued with specific religious meaning: the reinstatement of divine worship within the context of a theocratic national framework. The Zionist body acts in the material realm, but its innermost core aspires to eternal spiritual life, and this constitutes the "real" foundation for its operations and aims, even if the movement itself is still unaware of this. ${ }^{4}$

The followers of Merkaz Harav tried to integrate Kook's (senior) philosophy into Israeli reality. They have emphasized two key concepts: the holiness of the land of Israel and the holiness of the State of Israel. According to Rabbi Zvi Yehuda Kook (junior), the Land of Israel is one unity, a complete organic entity imbued with its own will and holiness. This entity is connected and united with the entire Jewish people-present, past and future-so that the people and the land are in a complete oneness. Therefore, no-one has a right to give any parts of the land, since it does not belong to one group than to another. ${ }^{5}$ This unity came as a result of the actions of the Zionist movement. Therefore, if the tool to implement God's will can be found in Jewish nationality then the Israeli state should be sanctified as part of the messianic process, even if it is secular. ${ }^{6}$

According to the Merkaz Harav philosophy, these two sanctities are expected to complement and complete each other. This has not always been reflected in Israeli reality, however. After the peace process between Israel and Egypt (1978) and the Israeli withdrawal from Sinai (1982), many Gush Emunim supporters were forced to confront the increasing erosion of their basic beliefs regarding the character and destiny of the State of Israel. The Israeli withdrawal from Sinai, and the subsequent Madrid talks (1991) and Oslo process (1993), 
which led to an Israeli withdrawal from parts of the West Bank, provoked a theological crisis. The fundamental religious dilemma is of a profound character: how can a state that uproots settlements and hands over parts of the Biblical Land of Israel to Arab rule be considered "absolutely sacred?" What sublime religious meaning can be attributed to the actions of a secular state which threatens to destroy by its own hands the chance of realizing the messianic hope? Could it be that viewing the Jewish state as a fulfillment of divine will was a mistake?

Against the background of these questions, I shall examine in this article the attitude of the rabbinical leadership among the settlers toward the Oslo process and the theological interpretations this entailed. I shall seek to ask whether the political process led to changes in terms of the status and religious meaning of the Zionist state, and how is the gulf bridged?

This article seeks to analyze the narrative and theological arguments of the religious leadership of the settlers. Accordingly, the discussion will focus on the formal discourse of two spiritual leaders of this stream, Yehuda Amital and Zvi Tau-heads of major yeshivot who are central figures whose thought influences the behavior of those who regard them as authorities. These two figures present distinct responses to the challenge created by the political process.

\section{COGNITIVE DISSONANCE}

The subject of prophetic failure is critical to an understanding of the development of any messianic faith. With this in mind, it is worth drawing on the theory of cognitive dissonance. In "When Prophecy Fails" (1956), Leon Festinger [and others] presented the salient features of this theory: The individual attempts to maintain his faith. If a person believes in something fervently; if he is committed to this faith and it has led him to take irreversible steps; then when confronted with irrefutable evidence that his faith is mistaken, the believer will only strengthen further his faith, making a renewed effort to convince and convert others to adopt his own worldview. Therefore, According to the theory, crisis of faith that results from prophetic failure may paradoxically lead to the strengthening of religious faith rather than to its dilution. While in logical terms the failure of the prophecy might be expected to weaken its justification, a diametrically opposite phenomenon sometimes develops, characterized by a strengthening of faith and religious practice in an attempt to set the messianic process back on course. 
The difference between expectations and experience generates cognitive tension. According to Festinger, the dissonance creates discomfort, thus producing pressure to reduce it. To this end, individuals must either change their beliefs, opinions, or behavior; secure new information that mitigates the dissonance; or forget or belittle the importance of the information that embodies an internal contradiction. In order to succeed in this, the believers must receive support from either their psychological or their social environment. Without such support, the chances are that the effort to moderate the dissonance will prove unsuccessful. Thus prophetic failure increases the believers' devotion and their proselytizing efforts. In some cases it is easier to cope with dissonance than to admit that a belief has failed. Accordingly, believers will not abandon their faith, but at the same time they cannot deny that it has failed to materialize. The believer must thus secure new information that corroborates their faith. This information lies in the determination that if more people can be convinced that their beliefs are correct, then clearly these beliefs indeed are correct. ${ }^{7}$

\section{TESTING FESTINGER'S THESIS}

Due to the central importance of the theory of cognitive dissonance in the study of the phenomenon of prophetic failure, it has also been examined by other scholars in additional studies. However, these studies have not necessarily reached the same conclusions as those presented by Festinger and his colleagues.

Accumulated research knowledge has shown that the response to a failure of prophecy generally tends to focus on mystical interpretations that deny the failure and argue that prophecy has been maintained on divine or ethereal levels. The liberating power of mysticism, especially in Jewish history, lies in the fact that it is rooted in paradox, exposing inner truth through externalities. ${ }^{8}$ Thus mystical interpretation enables the rejection of reality as it appears externally, and its presentation as covert spiritual fulfillment. The attribution of rationalization to failure may also be reflected in explanations that the crisis was a test of faith; that human errors occurred in calculations; or that others were to blame for the failure. ${ }^{9}$ A different course is also possible, however, that does relate to the fulfillment of prophecy in pragmatic terms, admitting failure and withdrawing from messianic expectations.

An example of this may be found in the history of the Sabbatean movement in the Jewish world. In his study, Gershom Scholem 
described how the Sabbatean movement split into two groupings following the conversion to Islam of its leader, Shabbtai Zvi in 1667. Following the prophetic failure, most of the supporters of the movement returned to normative Judaism. Those who remained in the movement adopted a mystical interpretation of their leader's conversion to Islam, depicting it as part of his battle against the forces of impurity. ${ }^{10}$ A more recent example from the Jewish world is the case of the Chabad movement, which crowned its leader, Rabbi MenachemMendel Schneurson as messiah and was then forced to confront his death in 1994. Following the failure, a split occurred within the movement between those who recognized his demise and thus concluded that he was not the messiah, and those who refused to accept this (some accepted that he had died but urged him to return to complete his mission, while others refused to accept his death, claiming that he was actually merely "concealing himself.") ${ }^{11}$

A further example is the Millerites movement, based on the leadership of William Miller, who calculated that the end of the world would arrive in 1843. After the calculation proved incorrect, he twice postponed the date to 1844. Festinger et al. claimed that after the third failure the movement collapsed, ${ }^{12}$ but this is inaccurate. After the failure of the calculation and the "great disappointment" this created, the supporters of the prophecy developed from a disorganized mass awaiting the end of the world into two distinct sects-the Advent Christian Association and the Seventh Day Adventist Church. ${ }^{13}$ The former of these sects admitted that the calculation had failed, but still expected the imminent coming of Jesus; the latter claimed that William Miller's prophecy had been accurate in terms of the date, but not in terms of the nature of the event. On the stated date, two prophecies of redemption and absolution out of three occurred, in the divine sphere. The third prophecy, they claim, will occur when God returns to earth. ${ }^{14}$

In a study into the Jehovah's Witnesses movement, which has experienced six failures to predict the end of the world, Joseph Zygmunt claimed that failure was interpreted as a call to the movement to arouse the members of the faith to redemption; accordingly, they argued, the prophecy had not in fact failed, but had been realized in the spiritual realm rather than in the physical realm. Failure in this world was perceived as partial realization in the divine world. They proposed that the divine plan resembles a jigsaw puzzle in which all the pieces must fall into place. Every day that passes brings redemption closer. ${ }^{15}$

Thus we can see that contrary to Festinger's theory, there is no single way that is used to overcome prophetic failure through conversion. The failure of prophecy does not necessarily mean the end of the 
movement. In some cases, failure can be interpreted as a trial of faith or a warning to the world. Accordingly, failure can paradoxically lead to the strengthening of the movement. True believers can continue to maintain their vision regardless of where it takes them, whether in logical or illogical terms. ${ }^{16}$

\section{“HEARING A BABY'S CRY”-POLITICAL REALITY AND MESSIANIC RETREAT IN THE THOUGHT OF RABBI YEHUDA AMITAL}

Until 2008, Rabbi Yehuda Amital served as head of Har Etzion Yeshiva in Gush Etzion. Amital is the founder of the yeshiva, which he ran jointly with Rabbi Aharon Lichtenstein. An important and respected rabbinical figure in the religious Zionist world, Amital has consistently presented moderate political opinions. Although he considers himself a loyal disciple of Rabbi Avraham Yitzhak Kook, Amital's practical interpretation of Kook's writings differs significantly from that developed in Mercaz Harav Yeshiva by Kook's son, Zvi Yehuda. This was not always the case, however. Rabbi Amital has undergone a profound theological transformation over the course of his life. Initially an enthusiastic supporter of the approach that views Zionist revival through the prism of a messianic process, as does Rabbi Zvi Yehuda Kook, Amital has withdrawn from the messianic interpretation of reality. Following this change, he presented an alternative religious program based on the demand for morality and justice as the manifestation of the Jewish way of life. ${ }^{17}$ This theological transformation occurred during the 1990s and, in my opinion, is closely connected to the political process of the Oslo accords. ${ }^{18}$

Rabbi Yehuda Amital (Klein) was born in 1924 in Transylvania, Hungary. During the Second World War he was taken to a forced labor camp; his relatives and other members of his community were sent to death camps. Amital has discussed the time he spent in the camps in many of his lectures. He often describes how a small booklet-Mishnat Harav-by Rabbi Avraham Yitzhak Hacohen Kook gave him spiritual strength during these difficult years, and accordingly he considers himself a disciple of Kook and someone who continues his course. In 1945, after the war ended, Amital immigrated to Palestine and continued his religious studies. A year after the Six Day War (1967), Amital established Har Etzion Yeshiva in Gush Etzion-the first settlement established in the occupied territories. His messianic views were well known in religious Zionist circles, and led Hanan Porat and Yoel Bin-Nun-who would later were among the founders of Gush Emunim-to ask Amital to head the yeshiva. In 1988, Amital founded the Meimad movement, which advocated a moderate 
religious position on political issues. Meimad participated in the general elections for the Knesset (which take place according to a multi-party proportional representation system), but failed to pass the electoral threshold. In 1996, Amital served in the Israeli government for several months as minister without portfolio following the assassination of Prime Minister Yitzhak Rabin by a Jewish assailant. Shimon Peres, who replaced Rabin as prime minister, urged Amital to join the government, which was responsible for continuing the political process with the PLO. After the Labor party lost the 1996 election and the Likud came to power, Amital once again devoted his time to his educational work as head of the yeshiva. ${ }^{19}$

His religious views underwent profound change. His first book"The Ascent from the Abyss" (1974)-is a collection of sermons given during and after the Yom Kippur War (1973) addressing the crisis of faith sparked by the war. The collection also includes sermons made by the rabbi during the 16 years preceding the war, from as early as 1958, supporting a religious approach that identifies the Jewish revival in the State of Israel as a manifestation of a messianic process.

In his book, Amital sought to present a paradoxical view of the Yom Kippur War, arguing that while its outcomes ostensibly suggest a messianic retreat, due to the Israeli military failures, the course of redemption remains unchanged. "It is confidence in the perception of the key events of this period as a single process leading toward the arrival of the Just Redeemer that led to the combination here of comments made in different periods," Amital declared in the introduction to the collection. ${ }^{20}$

Amital argues that people are obliged to seek to interpret events. Although mortals cannot fathom the considerations of divine providence, they must attempt to understand the theological significance of the war. The question is all the sharper, he adds, in view of what he terms "our certain belief" that this generation is living in a period of the "beginning of redemption." Given this certainty of historical processes, he argued, the outcomes of the war serve only to strengthen our impression that this is indeed a messianic process.

Amital draws on diverse arguments from the world of Jewish mysticism in order to explain why the war should be seen as the manifestation of a messianic process:

(1) The war erupted against the backdrop of the "resurrection of the kingdom of Israel," which in the future will completely alter the relationship between Israel and the other nations. Jewish nationhood in the State of Israel is a stage toward ultimate redemption. In a paradoxical and subconscious manner, this process provokes a profound sense of anxiety 
among the nations of the world, since the redemption of Israel will cause profound changes in the relations between Israel and the nations. Accordingly, Amital argues, what we are actually witnessing are the death throes of the Gentiles as an independent entity. This is the essential point of the war-the Gentiles are fighting for their very existence as Gentiles, as the impure. Evil is struggling for its right of existence, since it knows that when the ultimate redemption comes, there will be no place for Stan and the spirit of impurity. Accordingly, Amital concludes, the war rages against the background of the resurrection of the kingdom of Israel, and this is what imbues it with a messianic dimension.

(2) The fact that all the nations of the world participated in the war also reflects its messianic dimension. Amital claims that worldwide support for the Arabs reflects the mystical aspect of the war. "The cultural and moral collapse of Western Christian culture, the talk of the fellowship of nations and international solidarity, all emerges as empty and meaningless [...] Nothing can cover the obsequiousness of the leaders of the world before cultural and moral clowns, before dictators whose lands have been dominated by slavery and darkness since before medieval times."

(3) Israel's relative successes in the war, and the fact that Israel did not suffer a resounding defeat, are proof of divine intervention and miracles. The fact that despite the massive numerical superiority of the Arab forces, and the poor condition of the Israeli army, Israel managed to block the Arab armies was an overt miracle. "Surely this was in keeping with a divine command, since had [the Arab armies] not been stopped, they would have continued to race forward, burning and destroying everything.",21

These three conditions-a war against the background of the resurrection of the kingdom of Israel, the universal character of the war, and the appearance of great salvations, combined with the fact that the war erupted on Yom Kippur, all show that it had a messianic dimension.

Accordingly, the rabbi concludes that since the beginning of the Return to Zion (and Amital uses this religious term, which has a messianic meaning, in order to describe Zionist activity) there has been no retreat from the course leading to complete redemption. There may indeed be temporary concealments, but there is no retreat. All paths, paved or unpaved, lead to the redemption of Israel. ${ }^{22}$ 
Amital's belief in historical determinism led him to urge secular Zionism to make way for a "Zionism of redemption." He claimed that the confusion and distress caused by the war had revealed a deeper crisis in the central perception of Herzlean Zionism, with its vision of normalizing the Jewish people through its territorial concentration. He argued that the dream of eliminating antisemitism by establishing a Jewish state had proved to be an illusion. The State of Israel is the only country in the world that faces the threat of annihilation.

A different kind of Zionism also exists, however-one that does not seek to solve the Jewish question by establishing a Jewish state, but serves as an instrument for divine providence to advance Israel toward its redemption. "Its inner thrust is not the normalization of the Jewish people-to be like all the other nations, but rather to be a holy nation, the people of the living God, with its center in Jerusalem and the King's Temple within it.",3

Amital sees the intensive nature of the events that have marked Jewish history as part of the laws of redemption. It is important to emphasize that at the time, talking to combat soldiers while the fighting rages, Amital stressed that historical laws are operating in the history of the nation in this period. "Firstly Jews are led to the gas chambers like lambs to the slaughterhouse, and immediately after-a people rises like a lioness." During the Second World War the world ignores the existence of the Jews, yet within just a few years Israel is the focus of global attention. "The conclusion we must reach is that the ordinary laws of history that apply to the nations as a whole do not apply to Israel. Although it is an integral part of the family of nations, its historical laws are different from the historical laws of every other nation and tongue," Amital stated. The believing Jew has an explanation for this unique past and certain future. God has promised that the Jewish people will exist for eternity in order that it can fulfill its destiny: to manifest the divine ideal with the demand for practices of morality, justice, and law-a demand that applies to the entire people, and which can be met only in the Land of Israel.

An analysis of Amital's positions as published in 1974 already reflects a key distinction between himself, on the one hand, and Rabbi Zvi Yehuda Kook and the Mercaz Harav school of thought, on the other. Both Amital and Kook (junior) saw themselves as continuing the course of Rabbi Avraham Zvi Yehuda Kook (senior). Both viewed Israeli reality and history through the prism of messianic exegesis. But while Zvi Yehuda Kook sought to realize the messianic visions by clinging on to the soil and accordingly supported the settlement movement founded in 1974 as a tool for the realization of this approach, ${ }^{24}$ Amital's messianic vision focuses more on a state that aspires to justice and morality as a manifestation of the Kingdom of 
Priests and the Holy People. The activism Amital espoused was that of repentance-the traditional approach that saw repentance and redemption as intertwined. The traditional perceptions of redemption view it as the outcome of repentance; accordingly the purpose of exile is to prepare the people for the ultimate redemption, which will end when all repent. Redemption, therefore, is the product of the religious action of the people, and all that need be done in order to enter its gates is to observe the commandments. Complete redemption is preceded by complete repentance, when the entire people believes in its God and keeps all His commandments as written in the Torah and interpreted in the Halacha.

These differences, which were already apparent when Amital published his book and during the establishment of Gush Emunim, were to become more pronounced as the years passed. Zvi Yehuda Kook and his students supported the settler movement and established settlements in the West Bank and the Gaza Strip. These activities became a central feature of religious Zionism. By contrast, Amital's vision of the yearning for a moral and just society was marginalized on the agenda of the national religious camp. As religious Zionism was drawn towards right-wing politics, Amital was exceptional in terms of his left-leaning political views and his willingness to consider territorial compromise in order to avoid the loss of Jewish lives in wars and terrorist attacks.

Eventually, after a gradual process, Amital would completely abandon his messianic perspectives. According to Rabbi Moshe Maya, a graduate of Kfar Etzion Yeshiva and the author of an essay analyzing Amital's theoretical approach to the Holocaust-A World Built, Destroyed, and Rebuilt (2004), Amital stopped using messianic rhetoric in 1993 in the context of the description of Zionist reality. ${ }^{25}$ From this point on, I identify a new period in his religious approach.

In 1993, Amital published an article in the settlers' journal Nekuda expressing public, open, and unequivocal support for the political peace process. Entitled "There is Hope for the Zionist Settlement in Judea, Samaria, and the Gaza Strip," Amital declared that his support for the political process was due not to his support for the vision of peace embodied in the Oslo Accords, but rather to his grave concern at the possibility of war.

Out of his concern for the Jewish people, and in an effort to predict the future course of events, Amital argued that the growing strength of Arab fundamentalism raised the fear of a new war. Although he believed that Israel could overcome its enemies, the war would nevertheless have a disastrous effect on the country and on Israeli society.

Amital argued that any political agreement must include painful compromise. He believed that the formula of "peace for peace," 
without compromise, was completely unrealistic. At best, it reflected an approach that peace is impossible until the messiah comes. Otherwise it was no more than an empty platitude.

Time is not working in Israel's favor, he continued. Opportunities had been missed in the past to reach a peace agreement in better conditions. If no agreement was reached now, Israel would be required in the future to negotiate with Hamas.

Amital's support for the agreement was based on the fact that the Jewish settlements in Judea, Samaria, and the Gaza Strip were not included in the autonomy and were subject to exclusive and full Israeli control. He argued that this meant that the natural growth of the settlements would continue and there would be no freeze on construction.

After completing his political arguments, Amital turned to a discussion of theological questions. He began by attacking the centrality of the commandment of settling the Land of Israel among religious Zionist circles. He criticized the assumption that it is forbidden to relinquish Israeli sovereignty over even part of the Land, and placed the value of the supremacy of human life in apposition to the value of the Land of Israel.

Amital also opposed the use of the liturgical phrase "first shoots of our redemption" to describe contemporary reality. He claims that there are those who argue that since this is a process of redemption, the outcomes are predetermined, not only in terms of the end result of the process but also in terms of the certainty of success at every stage. "On the basis of this perspective, there is no need to pay any attention to actual reality, potential dangers, the political, social, and economic situation, or delays that may occur in the course of this process." Amital sought to offer an alternative approach based on the assumption that only the final outcome of the process is assured-the course of the process depends on human actions and behavior.

In his article, Amital noted that the political process may lead to a profound spiritual crisis. He warned against declining support for Zionism, which might come to be identified with "Hellenism"-a negative term used in Jewish culture to describe Jews who adopt the culture, and sometimes even the religion, of their non-Jewish surroundings. ${ }^{26}$

Around the same time (1994), Amital went still further in a conversation with his students, admitting that he had previously been mistaken and that Israeli reality does not reflect messianic reality. The rabbi used a parable to illustrate his error. He told his students about the author of the Tanya, Rabbi Shlomo Zalman of Liadi (the "Tanya"), the founder of the Chabad Hassidic movement. Zalman of 
Liadi studied Torah with his grandson (the "Tzemach Tzedek") in a three-room apartment ordered in such a way that the third, innermost room could be reached only through the middle room. The Tanya and the Tzemach Tzedek studied in two separate rooms, while in the third room a baby lay in a cradle. Suddenly the baby began to cry. The Tzemach Tzedek was so absorbed in his studies that he failed to hear the cries. The Tanya, who was in the furthest room, stopped his studies and went to soothe the baby. After he finished doing so, he passed through the room in which the Tzemach Tzedek was studying and told him: "When someone is learning Torah and fails to hear the crying of a Jewish baby, something is wrong with his studies."

This parable, which is often quoted with reference to Rabbi Amital, is interpreted as a criticism of religious Zionism, which he feels was so preoccupied with the settlement enterprise that it failed to pay sufficient attention to the needs of Israeli society and to struggle to build a state founded on morality and justice. In his talk with his students, however, Amital used the parable to make a further point. "I believe," he told them, "that whenever a yeshiva head only teaches Torah to others, and does not study it himself, something is wrong with his studies." Here he was suggesting that something had been defective in his own approach. He continued:

I have made an error, just as many have made errors. At the time I participated in the demonstrations against the [territorial] concessions when Kissinger came to Israel. Later I regretted this. After the Six Day War, Kissinger wanted us to make concessions to the Egyptians and retreat as far as Bir Jafjafa. If we had taken his advice, maybe the Yom Kippur War would not have erupted. I'm not saying that I had not made mistakes. But a Jew who has lived through the Holocaust; a Jew who has lived through five wars-the War of Liberation (1948), the Sinai Campaign (1956), the Six Day War (1967), the Yom Kippur War (1973), and the Lebanon War (1982), not to mention the War of Attrition (1967-1970)-I am allowed to be concerned about a further war. ${ }^{27}$

In addition to his pragmatic argument, which supports the political process on the basis of the sanctity of life, Amital continued to address the messianic question, explicitly stating that it is wrong to examine Israeli reality through the prism of messianism. He explained:

Friends, it is possible that all those who spoke of "the first shoots of our redemption" were mistaken. It is possible that the students of the Gaon of Vilna were mistaken; it is possible that the students of the Ba'al Shem Tov were mistaken; it is possible that the students of Rabbi Akiva Eger were mistaken, when they spoke of the "first shoots of our redemption" as the books state. It is possible that Rabbi 
Kook was mistaken; it is possible that Rabbi Harlap was mistaken. Even Rabbi Akiva, the great Tannaite, made mistakes. ${ }^{28}$

Amital's goal by making these comments was to deconstruct the entire historiography of the messianic strand within religious Zionism ${ }^{29}$-a single historical thread beginning in the dawn of the modern era with the messianic expectations among the students of the Ba'al Shem Tov, the founder of the Hassidic movement; ${ }^{30}$ continuing with the messianically inspired emigration to Palestine of a handful of the disciples of the Gaon of Vilna, one of the greatest Jewish scholars of the eighteenth century; ${ }^{31}$ and growing stronger with the activity of Rabbi Zvi Hirsch Kalischer, considered one of the "harbingers of Zionism" and a student of Rabbi Akiva Eger. ${ }^{32}$ He proceeds to argue that that the entire stream that developed on the basis of the thought of Rabbi Avraham Yitzhak Hacohen Kook may have been based on an erroneous foundation. Amital's mention of Rabbi Akiva is an extreme example-in his book Mishneh Torah (in the chapter Laws of Kings and their Wars, 11), Maimonides relates that Rabbi Akiva, the greatest of the Mishnaic sages, falsely crowned Bar Kochva as the messiah-king. ${ }^{33}$ (Bar Kochva, or Ben Kuziva, was the military commander who led the Jewish revolt against the Roman Empire during the reign of the Emperor Hadrian (132-135 AD); the rebellion was violently suppressed and hundreds of thousands were killed, including Bar Kochva himself). Rabbi Akiva declared Bar Kochva messiah in recognition of his intention to establish independent Jewish life; the establishment of a Jewish kingdom is part of the process of the resurrection of Israel, and this led to Rabbi Akiva's error. ${ }^{34}$ Amital's point is that if Maimonides can argue that Rabbi Akiva made an error, it is possible that Rabbi Kook (senior) made an error; and at this juncture Amital says that he himself is unsure and may have made an error.

Therefore Amital described the current period as one of "partial redemption:"

Complete redemption has not yet been realized in our times. We have not yet been privileged to see a state that is "the foundation of the throne of the Eternal Lord." But we have been privileged to see with our own eyes the ingathering of a large part of the dispersed Jews in their Land, and this phenomenon in itself may be considered tantamount to "the first shoots of redemption." Some of the characteristics of the period of redemption are already being revealed in our times. Even for a partial redemption that does not include all the components of complete redemption, let us say our thanks and praises to He who chooses His people Israel. ${ }^{35}$

In order to expedite complete redemption and the establishment of the idyllic kingdom of Israel, Amital concludes, Israel must do 
everything possible to establish a more just society based on worthy public values. "We must pay strict attention to moral values in our private and collective lives. Narrowing social gaps, attending to the weak in society, fighting poverty, and also treating the strangers who live among us fairly-all these will draw us closer to the day for which we long." 36

In conclusion, our analysis of the path taken by Rabbi Yehuda Amital highlights the profound transformation in his religious beliefs that led him to reject the messianic identification of Zionist action. This reversal occurred during the early stages of the Oslo process. As a result, the rabbi became a prominent advocate of the agreement, in order to prevent bloodshed against the changing reality of the Middle East.

The collapse of the Oslo process did not change his opinion regarding Israel need for pragmatic policies that would bring calm and peace to the region. In this regard, Amital opposed the Disengagement Plan, when Israel removed all of its settlements from the Gaza Strip and four settlements from northern Samaria (2005), because it was a unilateral act which he understood to be a measure that would only bring rise to terrorism, due to the lack of an accompanying peace agreement. ${ }^{37}$

Amital's approach in coping with messianic failure was to offer a pragmatic interpretation of reality. This enabled him to defuse messianic tension, admit that he had made a mistake, and retreat from messianic mysticism. Since Amital now argues that the process is not a messianic one, the Israelis should act in accordance with standards based on political considerations, as incumbent on the elected leadership of the nation. In order to aspire to an ideal society, Israel must act in a socially-responsible manner toward the weaker members of society, including the Arab population that lives in the Land of Israel.

\section{MESSIANIC MYSTICISM IN THE THOUGHT OF RABBI ZVI TAU}

Zvi Tau is one of the most prominent spiritual leaders who emerged from Mercaz Harav Yeshiva. He was a close disciple of Rabbi Zvi Yehuda Hacohen Kook, and many see him as following his path. In 1997, Tau broke away from Mercaz Harav Yeshiva following a disagreement with the head of the yeshiva, Avraham Shapira, regarding the inclusion of an academic teacher-training institute within the yeshiva framework. Tau was opposed to this innovation, left Mercaz Harav together with most of the teaching staff, and established Har Hamor Yeshiva, where he serves as the spiritual leader. ${ }^{38}$ 
Tau is one of the leaders of the "statist" stream in the philosophy of Mercaz Harav Yeshiva. This stream believes that Israeli nationhood enjoys a status of complete sanctity, insofar as it reflects the divine will for the redemption of Israel. On the basis of this value, those who follow the statist line reject the possibility of any physical opposition or any withdrawal from the course taken by the state. ${ }^{39}$

Unlike Rabbi Yehuda Amital, who underwent a religious transformation over the course of his life, Tau has remained consistent in his beliefs. Although the manner in which he describes secular reality has become increasingly extreme over the years, Tau remains faithful to his basic belief that the errors made by the state, and its failure to follow the messianic course, must be corrected solely by means of mass education in the ways of Torah.

The political process did not shake Tau's confident interpretation of Israeli reality as the reflection of mundane progress toward the ultimate redemption. Accordingly, he argues that the difficulties that result from the political process do not reflect any retreat. In fact, paradoxically, these setbacks form an integral part of the divine plan. ${ }^{40}$ Tau's religious approach and his responses to contemporary challenges reflect a pattern that perceive the crisis not as a set back but as a sign of strength. According to Tau's approach, the process of redemption is a long and complex one that includes tensions and profound contradictions between the ideal and reality. Yet his approach also continues the deterministic view that there can be only one sole interpretation of the Jewish past and of the Jewish future.

Tau argues that since the Jewish people constitutes a single organic unit, if this people includes even a single Jewish individual who does not accept the entirety of the Land of Israel with all his faith and conscience, this will blemish the entire nation. The existence of sections of the Jewish people who may not accept the need to hold on to all parts of the Whole Land of Israel dictates the task facing the present generation: to educate the public in the message of redemption. ${ }^{41}$ Even if the secular public has drawn away from the religious public in its opinions and thoughts, the entire Jewish people constitute a united entity, and redemption can develop only from the comprehensive revival of the people. ${ }^{42}$

The national revival of the Jewish people is built on two levels, sacred and profane. Each of these complements the other. Accordingly, Tau urged his audience to convey this message to the people; and thus there is a need for people of morality and faith to teach the sacred texts, so that when the age of redemption appears in all its greatness it will find a strong foundation enabling secular externality to adapt to the new reality. ${ }^{43}$ 
According to Tau, territorial retreats cannot lead to despair, since the path of mundane redemption is one that includes ascents and descents. Accordingly, events must be understood on the basis of their inner complexity, and not in a simplistic manner. The process of redemption also operates from within the darkness; the true believers must support it and help it to realize itself. ${ }^{44}$

Tau describes a process of redemption that is protracted and lengthy. It begins with the construction of the nation's body, and only thereafter moves on to the soul. Accordingly, if the present generation seems indifferent to morality and appears to be exclusively negative, this is a reflection of its greatness, not its insignificance. Even if there are problems, the religious people must recognize what hides behind them and understand the paradoxical nature of Jewish secularism in Israel.

Tau urges his audience to recognize the strength of historical dialectics. He argues that the course of redemption has led to a situation where not only sanctity is absent, but where empty secularity has even come to reject its own values. Discussing the phenomenon of post-Zionism, Tau suggests that empty secularity has created a paradoxical situation in which the absence of ideals actually makes the souls more inclined to accept sublime values and deeper and fuller understandings. This situation trains Jewish souls to accept the truth, i.e. to accept Torah and the commandments. In this way, God prepares for His return-through concealment, spoilage, and despair. ${ }^{45}$

The assassination of Israeli Prime Minister Yitzhak Rabin in 1995 brought Tau to sharpen his statist approach, in which he described this act as a severe desecration of the sanctity of the state. ${ }^{46}$ The failure of the Oslo Accords and the outburst of the second Intifada (Palestinian riots) 2001-2003 diminished the tension between the state and the settlers. However, shortly after the end of the riots, Israel Prime Minister Ariel Sharon, decided to disengage from Gaza.

As a result, Tau's rhetoric became increasingly exacerbated. In a book published prior to the implementation of the Disengagement plan, his description of the current generation became more extreme than ever. Tau offered a quasi-psychological explanation for the state of the secular public. He argued that the soul demands full sanctity. The present generation, however, has been educated to pursue honor and to gratify the most immediate and base desires. Accordingly, the soul emits sickness, sadness, and lack. In order to meet this need, it turns to the external dimension. "This explains the spirit of weakness regarding the abandonment of parts of the homeland," Tau determines. $^{47}$

Tau riles against poor moral values and the immodest dress of women and mocks the pursuit of external image. The loss of 
self-identity on the national level, he explains, has led to obsequiousness to the nations of the world. This has created the weakness that leads to the abandonment of sections of the homeland. The desire to satisfy the nations of the world leads to this degraded condition. The function of the public that is true to the tradition, accordingly, is to cure this sickness and to imbue the people with an alternative spirit based on pure ideals that does not seek permission or admiration from the nations of the world. The purification of the spirit is the main task facing Torah scholars. ${ }^{48}$

Why is the generation going from bad to worse? Tau's response emphasizes the mystical and paradoxical aspects of the process of redemption. He identifies an internal conflict within secularity-on the one hand, the soul longs to burst out; on the other, external forces keep it trapped inside.

Pride and impurity establish a hollow and vacuous world-a virtual reality behind which there is nothing. "An entire world is based on foundations of lies...In truth, in the internality of life all is rotten, devoid of love and true connection, and bereft of moral and human values. The inflated externality, it emerges, is intended to conceal the torments of the soul, covering all in a mud of crude desires in order to obliterate the longing for truth and good."49 Society is being demolished to its foundations, and "in such a situation, destruction must come, in order to shatter this corrupt framework and prevent it from continuing to exercise its damaging and corrupt influence." 50

Tau acknowledges that the modern period has secured enormous achievements in science, technology, and medicine. However, the desire for overall truth is disappearing. Tau describes modern culture in depressing terms; he views it as motivated by a false force that leads to the worship of human desires, tendencies, and pleasures. Humanity is conducting itself with complete nihilism and lack of values. The soul is being led to disintegration and bestiality. This culture, in which the divine image is vanishing, is a false one, and hence cannot endure. ${ }^{51}$

This desperate situation is a clarion call to rally behind the flag of Torah. The negative symptoms are not proof of failure, but powerful catalysts for elation. Tau argues that the cloaking and concealment of redemption actually reflect the birth of a new, sublime level that can appear only from within a tremendous crisis. The miserable reality prepares the ground for a more sublime appearance. The function of those who have faith, then, is to repair and strengthen-to educate and to illuminate the way. In natural redemption, everything must be done by mortals, and under the guidance of those who have faith. ${ }^{52}$

Tau's solution to this situation is a dialectical one. On the one hand, he urges his audience not to close in on itself or retreat due to despair. On the other hand, though, his solution is to create an 
enclave disconnected from the secular world by strengthening attention to learning and mental preparation. ${ }^{53}$ I would note here that the construction of enclaves that detach themselves from the influences of the secular world is a commonplace pattern of action in fundamentalist movements. ${ }^{54}$

The solution to the nation's distress and the path to redemption, Tau argues, lie in deeper study of Torah, and particularly study of mystical theories: "The more honest hearts are built in complete faith, the more this will illuminate-covertly, and hence also overtlyall reaches of the nation... We shall never abandon the foundation that determines everything, the very core of the battle: the building of the nation's minds and hearts, the direction of intellect and attention to the light of the "redeeming Torah.," 55

An analysis of the thought of Rabbi Tau identifies a response based on the call for religious reinforcement in response to the fear of a failure of faith. Tau urges his followers not to give in to the despair created by the political process and to continue their religious and faith-based course without change. When reality is perceived as contradicting the course of religious expectations, the solution is to adhere to the old course. For Tau, the way to cope with the challenge lies in a mystical perspective on reality, adopting an interpretation based on paradox and inversion. Thus only spiritual reinforcement based on mystical foundations can serve as a barrier between the illusive secular world and the hidden truth. Accordingly, Tau adheres to a course based on insularity and intensified sacred study, until the evil decree passes and the secular world implodes.

\section{CONCLUSION}

This article has examined different rabbinical responses to the messianic crisis created by the political process-a crisis that threatened to destabilize the religious perception of the State of Israel as a stage on the path to complete redemption. Since the emerging reality was seen to contradict faith, our study examined the responses of the spiritual leadership, offering a further opportunity to examine the theory of cognitive dissonance and test its validity.

The response of Rabbi Yehuda Amital is one of political realism, emphasizing the advantages of the political processes and the dangers that might ensue if it were not implemented. In adopting this position, Amital rejected the perception of Israeli reality as the manifestation of a divine plan for redemption. This enabled him to advocate political moderation and to shift the religious focus from settlement activism to 
social justice action. The retreat from the mystical interpretation of reality means that Amital did not follow the pattern proposed by the theory of cognitive dissonance, since political events actually led him to withdraw from his messianic expectations.

The response of Rabbi Zvi Tau represents the opposite trend. While Amital found a political response to reality, Tau sought to answer the challenge through a mystical and religious solution. $\mathrm{He}$ did not interpret the political process as reflecting any failure in messianic expectations; rather it was seen as a temporary obstacle to be overcome through heightened religious observance, in confident and optimistic anticipation that complete redemption will yet appear. The fact that reality does not necessarily support this assumption must not lead to despair or retreat; believers should continue their religious course without any change. The way to cope with the mental difficulty is through isolation and the establishment of an enclave that cannot easily be penetrated by the secular world. The emphasis on study of messianic mysticism is a further way to cope with the fear of failure, since Lurian mysticism by its very nature addresses the interpretation of historical paradoxes. Thus we can see that the theory of cognitive dissonance applies in this case-failure led not to a retreat from messianism, but to its reinforcement.

Secular Israeli reality presents a challenge for the religious structure of religious Zionism, which has been obliged to re-examine its basic assumptions concerning the purpose of the State of Israel. Cognitive dissonance is a central component in understanding their attitude toward the state, and one that has far-reaching ramifications. A mystical response to stubborn reality will strengthen messianic expectations, while a realistic response will tend to retreat from these expectations.

The article sought to expose additional features of the ways in which religious thought has coped with the secular world, examining the role of messianism as an activist phenomenon that continues to this day.

UNIVERSITY OF NORTH CAROLINA AT PEMBROKE

\section{NOTES}

1. Dov Schwartz, Religious Zionism: History and Ideology (Jerusalem, 2003), pp. 125-35 [in Hebrew].

2. Gershom Gorenberg, The Accidental Empire-Israel and the Birth of the Settlements, 1967-1977 (New York, 2006). 
3. On Kook senior see: Avinoam Rosenak, The Prophetic Halacha: Rabbi A.I.H. Kook's Philosophy of the Halacha (Jerusalem, 2007) [in Hebrew]; Zvi Yaron, The Philosophy of Rabbi Kook (Jerusalem, 1991) [in Hebrew].

4. Dov Schwartz, Faith at a Crossroads-A Theological Profile of Religious Zionism (Leiden, 2002), pp. 156-92.

5. Aviever Ravitzky, Messianism, Zionism, and Jewish Religious Radicalism (Chicago and London, 1993), pp. 122-44.

6. Ibid, pp. 136-41.

7. Leon Festinger, Henry W. Reiken, and Stanley Schachter, When Prophecy Fails (Minneapolis, 1956), pp. 3-32.

8. Gershom Scholem, Major Trends in Jewish Mysticism (New York, 1960), pp. 1-39.

9. Gordon Melton, "Spiritualization and Reaffirmation: What Really Happens When Prophecy Fails," American Studies, Vol. 26, No. 2 (1985), pp. 17-29; Lorne L. Dawson, "When Prophecy Fails and Faith Persists: A Theoretical Overview," Nova Religio, Vol. 3, No. 1 (1999), pp. 60-82.

10. Gershom Scholem, Sabbatai Sevi: The Mystical Messiah, 1626-1676, trans. R. J. Zwi Werblowsky (Princeton, 1973).

11. David Berger, The Rebbe, the Messiah and the Scandal of Orthodox Indifference (London, 2001); Simon Dein, "What Really Happens When Prophecy Fails: The Case of Lubavitch," Sociology of Religion, Vol. 62, No. 3 (2001), pp. 383-401.

12. Festinger, When Prophecy Fails, p. 22.

13. Ravid Rowe, Thunder and Trumpets-Millerites and Dissenting Religion in Upstate New York, 1800-1850: AAR Studies in Religion, Vol. 38 (1985).

14. Douglas Morgan, "The Adventist Tradition," in Introduction to New and Alternative Religions in America, ed. Eugene V. Gallagher and Michael Ashcraft (Connecticut and London, 2006), pp. 38-61.

15. Joseph F. Zygmunt, "Prophetic Failure and Chiliastic Identity: The Case of the Jehovah's Witnesses," American Journal of Sociology, Vol. 75, No. 6 (1970), pp. 926-48.

16. Jon Stone, Expecting Armageddon: Essential Readings in Failed Prophecy (London, 2000), pp. 1-30.

17. Alan Brill, "Worlds Destroyed, Worlds Rebuilt: The Religious Thought of Rabbi Yehuda Amital," The Eda Journal, Vol. 5, No. 2 (2006).

18. Moshe Maya, A World Built, Destroyed, and Rebuilt-Rabbi Yehuda Amital's Confrontation with the Memory of the Holocaust (Jersey City, NJ, 2004), pp. 55-56.

19. The biographical information is based on Moshe Maya, A World Built, Destroyed, and Rebuilt, pp. VII-VIII.

20. Yehuda Amital, Ascent from the Abyss-Comments on Contemporary Issues, Salvation, and Wars (Jerusalem, 5734 [1974]), p. 9 [in Hebrew].

21. Ibid., pp. 21-24.

22. Ibid., p. 31.

23. Ibid., p. 42. 
24. Dov Schwartz, "The Theological Justification for the NationalMessianic Philosophy: The Life Works of Rabbi Zvi Yehuda Kook," Zionism, Vol. 22 (2000), pp. 61-81 [in Hebrew].

25. M. Maya, A World Built, Destroyed, and Rebuilt, pp. 56-66.

26. Yehuda Amital, "There is Hope for the Zionist Settlement in Judea, Samaria, and the Gaza Strip," Nekuda, No. 172 (October 1993), pp. 42-45 [in Hebrew].

27. Yehuda Amital, "To Hear a Baby's Cry," from comments made in a conversation at the yeshiva, Hanukkah 5754 [1993]. See: Alonei EtzionCollection of Newsletters of Har Etzion Yeshiva (CD, Har Etzion Yeshiva, 5766 [2006]) [in Hebrew].

28. Ibid.

29. An example of the messianic philosophy may be found in a work by Rabbi Menachem Kasher, The Great Period: Chapters of Reflection on the State of the Nation and Our Land (Jerusalem, 1962) [in Hebrew].

30. See: Mor Altshuler, The Messianic Secret of Hassidism (Leiden, 2006).

31. Aryeh Morgenstein, Messianism and the Settlement of the Land of Israel in the Nineteenth Century (Jerusalem, 1987) [in Hebrew].

32. Judy Meyers, Seeking Zion: Modernity and Messianic Activism in the Writings of Tsevi Hirsch Kalischer (Oxford, 2003).

33. David Hartman, "Maimonides' Approach to Messianism and its Contemporary Implications," Daat, Vols. 2-3 (1978/1979), pp. 5-33.

34. Yehuda Amital, "Sing unto Him, Sing praises unto Him, Speak of All His Marvelous Works," comments made in a conversation on the eve of Independence Day 5756 [1995], Alonei Etzion (CD) [in Hebrew].

35. Yehuda Amital, "The Religious Significance of the State of Israel," edited on the basis of a conversation at the yeshiva on Hanukkah 5757 [1997], Alonei Etzion, also published in Alon Shvut Alumni, Vol. 11 [in Hebrew].

36. Ibid.

37. Elyashiv Raikhner, Beemunato: The Story of Harav Yehudah Amital (Tel-Aviv, 2008), p. 254 [in Hebrew].

38. Yishai Rosen-Zvi, "Metaphysics in the Making: The Dispute at Mercaz Harav Yeshiva-A Critical Study," in One Hundred Years of Religious Zionism-Ideological Aspects, (eds) Avi Sagi and Dov Schwartz (Ramat Gan, 2003), pp. 421-46 [in Hebrew].

39. Motti Inbari, "Fundamentalism in Crisis-The Response of the Gush Emunim Rabbinical Authorities to the Theological Dilemmas Raised by Israel's Disengagement Plan," Journal of Church and State, Vol. 49, No. 4 (2007), pp. 709-11.

40. Zvi Tau, On the Faith of Our Times-Guidelines for Understanding the Period (Jerusalem, 1994), Vol. 1 (in Hebrew).

41. Ibid.

42. Ibid., p. 25.

43. Ibid., pp. 34-43.

44. Ibid., pp. 70-84.

45. Ibid., pp. 90-99. 
46. Yair Sheleg, The New Religious Jews: Contemporary Overview on Israel's Religious Society (Jerusalem, 2000), pp. 49-50 (in Hebrew).

47. Zvi Tau, On the Faith of Our Times-Guidelines for Understanding the Period, Vol. 7 (Jerusalem, 2006), pp. 48-49.

48. Ibid., p. 52.

49. Ibid., p. 61.

50. Ibid., p. 62.

51. Ibid., pp. 190-94.

52. Ibid., pp. 160-61.

53. Dov Schwartz, Challenge and Crisis in the Circle of Rabbi Kook (Tel Aviv, 2001), pp. 136-38 [in Hebrew].

54. Gabriel A. Almond, Scott R. Appleby, and Emmanuel Sivan, Strong Religion-The Rise of Fundamentalism around the World (Chicago, 2003), pp. 23-89.

55. Z. Tau, On the Faith of Our Times, Vol. 7: p. 263. 